\title{
Pergeseran Fungsi Tari Berutuk dari Desa Trunyan, Bali
}

\author{
Oleh: Fisabil Mahardika Putra
}

Jurusan Politik dan Pemerintahan, Fakultas Sosial dan Politik

Universitas Gadjah Mada Yogyakarta

E-mail: fisabilmahardikaputra@gmail.com

\begin{abstract}
RINGKASAN
Tulisan ini menjawab pertanyaan tentang fungsi tari Berutuk dari desa Trunyan, Bali. Pertunjukan tari ini dilakukan oleh laki-laki yang masih perjaka berjumlah ganjil, namun yang umum dilaksanakan berjumlah 21 orang. Para penari berutuk ini merupakan simbol dari penjaga Ratu Sakti Pancering Jagat beserta permaisurinya. Pakaian yang digunakan terbuat dari daun pisang kepok yang kering dan menggunakan topeng.

Pada awalnya kesenian Berutuk sangat disakralkan karena dapat memberi kesejahteraan masyarakat setempat dengan perwujudan datangnya hujan, namun sejak tahun 1997 mengalami desakralisasi. Saat ini kesenian tersebut mengalami pergeseran fungsi karena modenisasi dimana menggunakan pendekatan rasionalisme yang mana rasional bertolak belakang dengan takhayul. Artinya kesenian tersebut dapat diselenggarakan dengan sangat sakral, tetapi juga dapat diselenggarakan untuk kepentingan hiburan atau kesenian semata.

Untuk menjawab semua pertanyaan tersebut, penelitian ini menggunakan metode studi kepustakaan. Teori yang digunakan adalah teori rasional dimana teori tersebut berhasil menjawab bahwa pergeseran fungsi tari berutuk dikarenakan rasio. Teori ini tidak mempercayai hal-hal yang tidak rasional.
\end{abstract}

Kata kunci : tari Berutuk, desakralisasi, pergesaran fungsi

\section{ABSTRACT}

This article answers the question of what is a berutuk dance art from the village of Trunyan, Bali where the history of the arts is very sacred, then answer the question how the implementation of the arts, and why now since 1997 has desacralized. The result of research, the art of berutuk begins with sacred art, because it can give the welfare of the local community with the embodiment of the coming rain. Implementation is played by a male who still virgin with an odd number. 
Currently the arts are shifting functions because of modenisasi where using a rationalism approach which is rational contrary to superstition. This means that art can be held with a very sacred, but also can be held for the sake of entertainment or art alone. To answer all these questions, this research uses literature study method. The theory used is a rational theory in which the theory successfully answered that the shift of the dance function is condemned due to the ratio. This theory does not believe in things that are not rational.

Keywords: Berutuk dance, desacralization, function

\section{PENDAHULUAN}

Berbicara tentang konteks seni atau kesenian tentunya tak lepas dari kesejarahannya. Kesenian yang ada di dunia ini tentunya sangat beragam, dan tentu memiliki sejarahnya masing-masing. Begitu juga dengan kesenian yang ada di Indonesia yang mana negara ini memiliki kebudayaan yang sangat beragam. Bahkan dapat dikatakan bahwa Indonesia tidak dapat disebut Indonesia kalau tidak beragam kebudayaan dan keseniannya.

Pada masa prasejarah yaitu ratusan tahun sebelum tarikh Masehi sampai abad pertama Masehi, diperkirakan bahwa kesenian Indonesia, khususnya seni pertunjukan berkembang baik. Akan tetapi peninggalanpeninggalan tersebut sampai ke kita tidak cukup banyak. Meski demikian, kita masih tetap bisa menilik peninggalan-peninggal tersebut jika ada benda-benda peninggalan arkeologi, biasanya benda-benda tersebut terkait dengan upacara penyembahan roh nenek moyang, animisme, serta kepercayaan terhadap binatang atau totem. ${ }^{1}$

Salah satu peninggalan kesenian nenek moyang yang ada di Pulau Bali, tepatnya di Desa Trunyan adalah "berutuk". Dipilihnya kesenian ini dikarenakan masih banyak masyarakat Indonesia, bahkan masyarakat Bali itu sendiri yang tidak tahu tentang kesenian tersebut. Hanya sebagian masyarakat yang biasanya tahu tentang kesenian tersebut seperti sebagian masyarakat akademisi (khususnya tari), budayawan Bali, masyarakat Desa Trunyan sendiri, sebagian masyarakat Bali Timur dan sebagaianya. Ditambah lagi dengan rasa penasaran tentang sebab kesenian ini yang dulunya sangat sakral bergeser menjadi sebuah pertunjukan yang dapat dipertunjukan sebagai kesenian semata untuk umum, tetapi dalam

${ }^{1}$ Soedarsono, 2002, Seni Pertunjukan Indonesia di Era Globalisasi, Yogyakarta, Gadjah Mada University Press,p. 8 
wilayah adat masih tetap sakral. Dalam penulisan ini, penulis akan menulis tentang apa itu kesenian tari berutuk? dan bagaimana proses dan implementasi pertunjukan kesenian tersebut? Dan kenapa kesenian tari tersebut mengalami perubahan dari sakral menjadi desakralisasi? Atau mengalami pergeseran fungsi dari kesenian yang hanya bisa dilakukan secara sakral menjadi kesenian yang lebih fleksibel, yaitu kesenian yang dapat dilakukan untuk sebuah pementasan umum di mana tidak ada poin-poin kesakralan.

Peninggalan-peninggalan arkeologi yang usianya sudah ribuan tahun masih dapat ditemui oleh masyarakat Nusantara (masyarakat pada sebelum jadi Indonesia (NKRI), atau yang sudah jadi Indonesia). Terkadang masyarakat yang diwarisi bendabenda arkeologi tersebut hingga kini masih sering mendapatkan interpretasi baru. Berkaitan dengan hal tersebut, di Desa Trunyan yaitu di Bali Timur ditemukan patung batu lelaki yang memiliki alat vital yang sangat besar. Pahatannya masih sangat kasar. Peninggalan tersebut merupakan peninggalan dari zaman Megalitikum. Dalam kepercayaan agama Hindu, patung tersebut lazim disebut Batara Berutuk. Patung tersebut ditempatkan di tempat yang sangat terhormat oleh masyarakat sekitar. Masyarakat sekitar memiliki kepercayaan, bahwa Batara Berutuk adalah nenek moyang mereka yang sangat sakti, sehingga benda arkeologi tersebut dikeramatkan oleh masyarakat sekitar. Karena begitu keramatnya, maka patung tersebut diberi nama oleh penduduk dengan nama yang sangat terhormat, yaitu Ratu Sakti Pancering Jagat. Ia memiliki permaisuri yang dilambangkan tempat duduk yang ditempatkan di tempat yang disucikan atau disebut dengan Penaleman. Gelar permaisuri tersebut adalah Ratu Ayu Pingit Dalam Dasar. ${ }^{2}$ Kedua tokoh tersebut adalah tokoh yang paling dihormati oleh masyarakat Desa Trunyan. Kesenian berupa tarian yang disebut berutuk ini adalah klimaks dari serangkaian upacara untuk mendatangkan kesejahteraan dimana kehadiran hujan sebagai perwujudannya.

\section{PEMBAHASAN}

\section{A. Persiapan dan Persyaratan Sebelum Melaksanakan Tari Berutuk}

Ada beberapa sesi dalam pelaksanaan upacara adat tersebut. Di sesi awal adalah sesi persembahan-persembahan dan doa-doa. Setelah sesi doa-doa dan persembahanpersembahan usai, maka ada sesi pertunjukan dimana sesi ini adalah bagian klimaksnya dari upacara tersebut, yaitu tari berutuk dengan pakaian dan bahan-bahan riasnya yang sudah dido'akan terlebih dahulu. Dipersiapkan beberapa lelaki yang mana biasannya terdiri dari 21 lelaki yang masih perjaka, setidaknya

\footnotetext{
${ }^{2}$ Ibid, hlm. 9
} 
ganjil, bisa kurang bisa lebih. Lelaki perjaka yang wajib adalah lelaki yang paling tua di antara saudara-saudaranya.

Kesenian pertunjukan tari berutuk ini memiliki cara berpakaian yang masih sangat tradisional, yaitu berpakaian dengan daun pisang kepok yang kering dimana harus dipersiapkan dengan detail. Daun pisang kepok yang kering tersebut tidak sembarang tempat didapat. Daun pisang tersebut harus diambil dari desa yang dekat dari Desa Trunyan, yaitu Desa Pinggan, Bayung, dan Blandingan. Begitu juga alat riasnya tidak dapat sekedarnya saja. Alat rias yang dipakai adalah harus tanah liat yang didapat di Song Rerindi atau goa hantu di mana bertempatan di dekat Desa Trunyan juga, lalu dicampur dengan kunyit dan wewangian. Tentunya kostum dan bahan rias sudah didoakan ketika sesi awal yaitu sesi doa-doa dan persembahan. Terakhir para penari diharuskan memakai topeng yang sudah ada sejak lama dan tidak rusak. Rata-rata topeng tersebut berjumlah 21 buah.

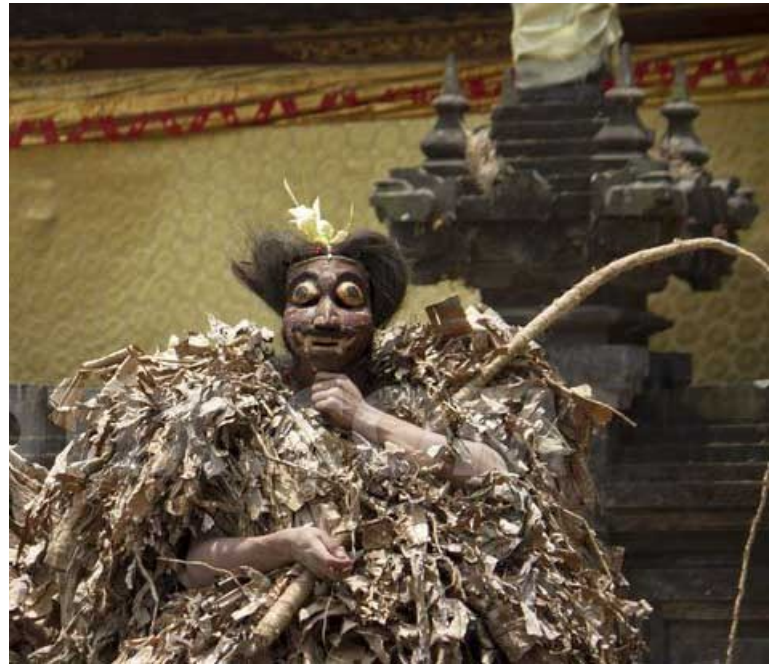

Gambar 1. Kostum tari berutuk ${ }^{3}$

Pertunjukan tari berutuk merupakan puncak dari serangkaian upacara adat di Desa Trunyan. Nama dari upacaranya adalah Saba Gede Kapat Lanang. Karena upacara tersebut sangat sakral maka ada ketentuan upacara agar upacara tersebut dapat mempengaruhi alam setelah usai dilaksanakan. Ketentuanketentuan tersebut adalah upacara Saba Gede Kapat Lanang harus dilaksanakan ketika bulan kapat atau bulan keempat (menurut perhitungan masyarakat Desa Trunyan). Lalu keadaan desa harus sedang makmur atau sedang dalam bersih secara spiritual, seperti tidak mengalami musim panas/kemarau yang berkepanjangan dan tidak ada yang meninggal dunia selama bulan tersebut, kemudian tidak ada ibu yang melahirkan kembar buncing (kembar laki-laki dan perempuan).

\footnotetext{
${ }^{3}$ Diunduh dari

http://new.babadbali.com/featured/2016/seni-dramadan-tari/ pada tanggal 19 Desember 2017, pukul 16.07 WIB
} 


\section{B. Pelaksanaan Kesenian Berutuk}

Seperti yang telah dikatakan di atas, bahwa kesenian tari ini terdiri dari rata-rata 21 lelaki perjaka, bisa kurang, bisa lebih tergantung jumlah topeng. Para penari berutuk ini merupakan simbol dari penjaga Ratu Sakti Pancering Jagat beserta permaisurinya.

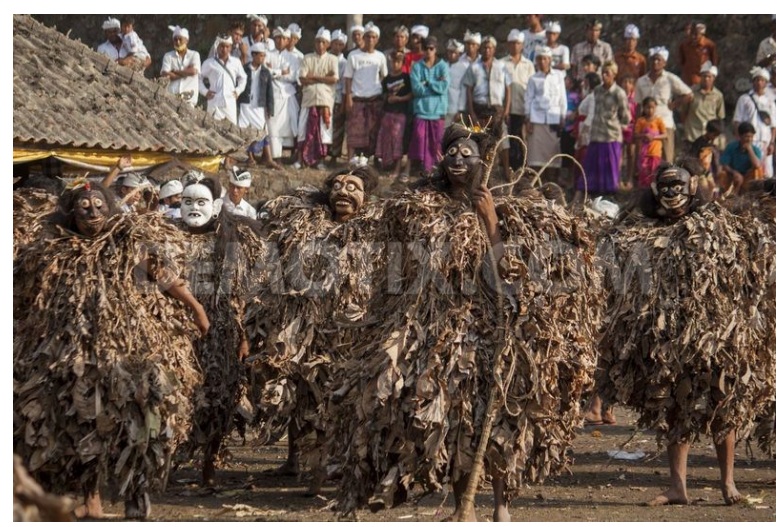

Gambar 2. Kelompok penari berutuk ${ }^{4}$

Para berutuk memiliki senjata berupa cambuk atau pecut dimana penduduk Desa Trunyan mempercayai bahwa cambukan berutuk bisa menyembuhkan penyakit. Bahkan serpihan dari robekan daun pisang kepok kering pakaian penari berutuk dapat juga menjadi jimat dan dapat mendatangkan hujan. Para berutuk menari sambil berkeliling desa dan mencambuk siapa yang mau dicambuk, lalu pada bagian terakhir ada pertunjukan tari berutuk yang dilakukan oleh 2 penari berutuk.

\section{${ }^{4}$ Diunduh dari}

https://www.wonderfulbali.com/trunyan-traditionalbali-village/ pada tanggal 19 Desember 2017, pukul 17.05 WIB

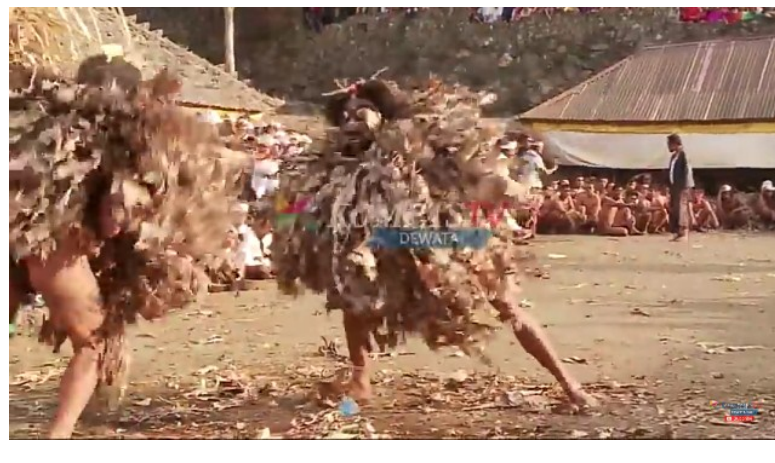

Gambar 3. Dua berutuk

Kedua berutuk tersebut menyimbolkan satu lelaki dan satu wanita. Mereka saling menghalangi arah lawannya mau pergi, lalu ditutup dengan saling berpegangan. Hal ini menyimbolkan bahwa warga Desa Trunyan dulu sangat sulit dalam mencari pasangan hidup. Upacara Berutuk ini dikemas sedemikian rupa hanya untuk masyarakat Desa Trunyan saja, bukan untuk umum.

Pelaksanaan kesenian berutuk tersebut sangatlah jarang, karena sulitnya penempatan waktu yang pas dengan syarat-syarat yang terkadang sulit dikerjakan, tetapi terkadang syarat tersebut menjadi gampang dikerjakan karena kondisi yang sesuai, seperti memang tidak ada kematian, desa tersebut makmur dan sebagainya. Di abad 20 ini saja upacara tersebut beritanya hanya dapat dilaksanakan secara sungguh-sungguh, hanya 3 kali saja, yaitu tahun 1930, 1970 dan 1980. Namun perlu digaris bawahi, bahwa meski masyarakat Trunyan menganggap kesenian tari berutuk sangat sakral, akibat dari melandanya Era

${ }^{5}$ Screenshoot dari video dokumentasi Dewata TV, publikasi tanggal 6 desember 2014 
Globalisasi, di tahun 1997, masyarakat Trunyan berani menggelar kesenian tari berutuk tersebut untuk dipentaskan secara umum yaitu pada pesta kesenian Bali yang dibuka oleh wakil presiden Indonesia. ${ }^{6}$ Tari berutuk pada pertunjukan pesta kesenian Bali 1997 tersebut tentunya pertunjukan yang sudah tidak sakral lagi, karena diperuntukan bukan intern masyarakat Trunyan sendiri tetapi untuk kepentingan umum. Dalam hal ini berarti kesenian tari berutuk telah mengalami desakralisasi yang merupakan dampak dari modernisasi. $^{7}$

\section{A. Analisa Pergeseran Fungsi Tari Berutuk}

Semakin kesini maka efek modernisasi semakin meningkat. Bukti dari peningkatannya adalah teknologi dan media yang semakin berkembang. Semakin maju teknologi dan media, maka fenomena desakralisasi khususnya pada kesenian berutuk akan semakin kuat. ${ }^{8}$ Hal tersebut beriringan atau bergerak similar karena dengan semakin media masuk khususnya masuk ke Indonesia, sedangkan yang membuat media adalah orang barat (budaya barat), maka ilmu-ilmu sains yang notabene berasal dari barat dimana tidak

${ }^{6}$ Soedarsono, 2002, Seni Pertunjukan Indonesia di Era Globalisasi, Yogyakarta, Gadjah Mada University Press, hlm. 11

${ }^{7}$ Ibid, hlm. 11

${ }^{8}$ Lang, Maduro, The Desacralization of Marxism within Latin American Liberation Theology, Social Compass, XXXV/2-3, 1988, 371-385 mengenal hal-hal yang tidak masuk akal atau takhayul, masuk kedalam budaya Indonesia. Sedangkan sains adalah keilmuwan yang masuk di akal atau rasional. Jadi lawan dari takhayul adalah rasional. Adapun ideologi yang menaunginya yaitu rasionalisme.

Membahas tentang rasionalisme, tak lepas dari asal katanya, yaitu rasio. Rasio merupakan pemikiran menurut akal yang sehat. ${ }^{9}$ Pelaku dari faham ini disebut rasionalis. Jika didefinisikan, rasionalisme adalah aliran filsafat ilmu yang berpandangan bahwa otoritas rasio (akal) adalah sumber dari segala pengetahuan. Dengan demikian berarti kriteria-kriteria kebenaran berbasis pada intelektualitas. Sehingga cara atau metode pengembangan ilmu menurut rasionalisme adalah mengeksplorasi gagasan-gagasan dengan menggunakan kemampuan intelektual manusia dimana akal yang menjadi pusat atau sumber kerjanya. ${ }^{10}$ Gagasan atau faham ini diusung oleh filusuf-filusuf barat pada abad pertengahan, yaitu Socrates, Plato dan Aristoteles. Puncak kejayan rasionalisme pada zaman Aristoteles, lalu dikembangkan di era modern oleh Rene Descartes dimana Descartes akhirnya mendapat julukan bapak filsafat modern. Adapun semangat yang melatar belakangi rasionalisme adalah keinginan untuk

${ }^{9}$ Bahar, H. Muhammad, Rasionalis dan Rasionalisme dalam Perpektif Sejarah, Jurnal Ilmu Budaya, Vol 4, No. 2, Desember 2016, ISSN : 23547294

$$
{ }^{10} \text { Ibid }
$$


membebaskan diri dari segala pemikiran tradisional. Jargon yang dipakai Descartes adalah "saya berfikir maka saya ada". ${ }^{11}$ Sehingga pengembangan pengetahuan dengan cara terus berfikir menggunakan akal.

Berkembangnya teknologi dan media itu adalah wujud dari modernisasi. Modernisasi muncul dari budaya barat yang mana orang barat selalu menggunakan akal pikiran sehatnya untuk pengembangan pengetahuan, berarti perkembangan teknologi dan media tentunya jelas menggunakan akal sehat (rasio) manusia. Maka rasio atau akal sehat bertolak belakang dengan takhayul. Dalam tulisan ini, tari berutuk merupakan kesenian yang sangat sakral. Maksud dari sakral adalah hal-hal yang berbau dengan takhayul atau hal-hal yang tidak masuk akal. Jadi ketika masyarakat Desa Trunyan yang tergabung dalam rakyat Indonesia ini mengalami modernisasi, perwujudan modernisasi berupa adanya media televisi, alat komunikasi, kendaraan bermotor, bersekolah, membaca dan sebagainya, berarti masyarakat Desa Trunyan telah mulai kebarat-baratan. Dengan bersekolah berarti masyarakat tersebut berkembang dengan menggunakan akal sehat. Semakin akal sehat itu berkembang (semakin rasional) maka tingkat pemikiran yang takhayul atau yang tidak masuk akal dan tradisional akan semakin terkikis menjadi berfikir yang modern. Dengan terkikisnya pemikiran yang takhayul maka sakralisasi hasil dari pemikiran yang takhayul juga similar terkikis. Dengan terkikisnya pemikiran takhayul di desa trunyan, berarti masyarakat tersebut semakin rasionalis. Jika hal tersebut terus berkembang maka akan menjadi masyarakat yang modern (pergeseran cara berfikir tradisional ke modern). Hal ini adalah perwujudan kinerja rasionalisme, yaitu ingin terbebas dari segala pemikiran yang tradisional. Dengan begitu berarti wajar saja jika semakin kesini kesenian tari berutuk mengalami desakralisasi. Desakralisasi tersebut terjadi oleh masyarakatnya sendiri karena masyarakatnya yang semakin modern.

Sekelebat penulis berfikir bahwa Indonesia memiliki dua musim yaitu musim kemarau dan musim penghujan. Oleh karena itu sangat wajar terjadi hujan ketika upacara tersebut dilakukan ketika transisi dari musim kemarau ke musim penghujan. Sekilas pemikiran modern tentunya mengatakan seperti itu berdasarkan rasio. Sangat dimungkinkan masyarakat Desa Trunyan kurang lebih berfikir sama meski tidak persis, karena hasil dari pengetahuan rasio mereka sebagai masyarakat modern. Jadi, kesenian tari berutuk kini mengalami pergeseran fungsi dari kesenian yang sangat sakral dimana berfungsi untuk sebuah kesejahteraan masyarakat setempat dan diselenggarakan secara intern, 
menjadi kesenian yang mengalami desakralisasi ketika kesenian tersebut diselenggarakan untuk kepentingan umum seperti kepentingan kebudayaan Bali secara khusus dan kebudayaan Indonesia secara umum. Akan tetapi pada acara intern kesenian tersebut masih tetap diselenggarakan secara sakral.

\section{PENUTUP}

Kesenian tari berutuk merupakan kesenian yang berasal asli dari Desa Trunyan Bali Timur. Kesenian tari ini merupakan salah satu dari prosesi upacara Saba Gede Kapat Lanang. Upacara tersebut adalah pemujaan terhadap roh nenek moyang yaitu Batara Berutuk yang mana memiliki julukan Ratu Sakti Pancering Jagat dan memiliki permaisuri yaitu Ratu Ayu Pingit Dalam Dasar. Upacara tersebut dilakukan untuk sebuah permohonan kepada Ratu Sakti Pencering Jagat agar mendatangkan kesejahteraan dengan perwujudan hadirnya hujan. Oleh karena itu upacara tersebut sangat disakralkan oleh masyarakat setempat. Karena sakral, upacara tersebut tertutup hanya untuk masyarakat setempat saja serta sangat jarang di lakukan. Terbukti pada abad 20, upacara Saba Gede Kapat Lanang ini hanya dilakukan sebanyak 3 kali yaitu pada tahun 1930, 1970 dan 1980.

Dalam pelaksanaannya, seni tari berutuk digelar ketika sesudah sesi doa dan persembahan. Kesenian tari berutuk tersebut adalahh klimaks dari prosesi upacara. Tari berutuk tersebut diperankan oleh lelaki perjaka dengan jumlah yang ganjil, biasanya sebanyak 21 penari dengan memakai pakaian dari daun pisang kepok yang kering yang didapatkan dari desa Pinggan, Bayung dan Blandingan. lalu dirias dengan tanah liat dari Song Rerindi atau goa hantu yang dicampur dengan kunyit dan wewangian dimana daun pisang kepok kering dan riasannya sudah didoakan terlebih dahulu. Mereka membawa cambuk sebagai simbol senjata untuk melindungi Batara Berutuk. Siapa yang mau dicambuk maka dipercaya akan sembuh dari penyakit, bahkan serpihan dari sobekan daun pisang kepok kering pakaian penari tersebut bisa menjadi jimat dan dapat mendatangkan hujan.

Kemudian pada tahun 1997, masyarakat Trunyan berani menampilkan pertunjukan tari berutuk ini pada Pesta Kesenian Bali yang dibuka oleh Wakil Presiden Indonesia. Fenomena pada tahun 1997 tersebut merupakan fenomena bersejarah bahwa kesenian yang sangat sakral tersebut mengalami desakralisasi. Hal tersebut terbukti bahwa yang semula kesenian tersebut untuk kebutuhan intern masyarakat Desa Trunyan, berpindah menjadi kebutuhan umum yaitu Pesta Kesenian Bali dimana ketika itu tari berutuk menjadi tidak ada sakralnya sama sekali dan murni pertunjukan. Fenomena 
tersebut menimbulkan pertanyaan bahwa kenapa masyarakat setempat berani menampilkan kesenian tari berutuk yang sangat sakral, yang biasanya untuk intern, ditampilkan didepan umum. Fenomena tersebut menggambarkan bahwa kesenian tari berutuk telah mengalami desakralisasi oleh masyarakatnya sendiri. Semakin kesini masyarakat tersebut semakin modern. Asasasas modernisasi yang ditokohi oleh filusuf bernama Rene Descartes adalah berfikir rasional. "Saya berfikir maka saya ada" merupakan jargonnya. Berfikir ini adalah halhal yang berhubungan dengan akal sehat atau rasio. Dalam fahamnya adalah rasionalisme. Faham rasionalisme ini adalah salah satu asas modernisasi. Saat ini sebagian besar Masyarakat Desa Trunyan bersekolah. Bersekolah adalah sarana merasionalisasikan para siswanya. Berarti masyarakat desa trunyan sudah teracuni modernisasi. Dalam konteks pelaku-pelaku kesenian berutuk, maka semakin tumbuh modernisasi maka semakin tumbuh juga desakralisasi oleh pelaku-pelaku kesenian tari berutuk sendiri. Hal tersebut dikarenakan rasionalisme berlawanan dengan hal-hal yang tidak masuk akal atau takhayul. Sehingga melihat fenomena masyarakat Desa Trunyan yang sedang modern ini, menjadikan sebuah kewajaran bahwa kesenian tari berutuk mengalami desakralisasi oleh masyarakatnya sendiri. Akibat dari faham rasionalisme yang telah merasuk dalam kehidupan masyarakat Desa Trunyan maka kesenian berutuk menjadi kesenian yang lebih fleksible. Ketika digelar dalam upacara adat secara intern, maka kesenian tersebut sangat sakral. Tetapi ketika digelar untuk kepentingan umum berarti kesenian tersebut mengalami desakralisasi, karena digelar dengan tujuan bukan untuk kesejahteraan masyarakat setempat, tetapi untuk murni sebuah pertunjukan seni yang salah satunya memiliki sifat menghibur penontonnya.

\section{DAFTAR SUMBER ACUAN}

\section{A.Sumber Tertulis}

Soedarsono, 2002, Seni Pertunjukan Indonesia di Era Globalisasi, Yogyakarta, Gadjah Mada University Press

Rendra, 1984, Mempertimbangkan Tradisi, Jakarta, PT. Gramedia

Lang, Maduro, The Desacralization of Marxism within Latin American Liberation Theology, Social Compass, XXXV/2-3, 1988, 371-385

Bahar, H. Muhammad, Rasionalis dan Rasionalisme dalam Perpektif Sejarah, Jurnal Ilmu Budaya, Vol 4, No. 2, Desember 2016, ISSN : 2354-7294

\section{B. Webtografi}

https://www.wonderfulbali.com/trunyantraditional-bali-village/ http://new.babadbali.com/featured/2016/senidrama-dan-tari/ 